let count should be performed in all patients with peripheral vascular disease.

We are grateful for financial suppont for some of this work from the Endowment Research Fund of the United Sheffield Hospitals.

\section{Addendum}

Since preparing this report two similar cases (one man and one woman) have been investigated and treated by us.

\section{References}

Biermé, R., et al. (1972). Lancet, 1, 432.
Fountain, J. R., and Losowsky, M. S. (1962). Quarterly fournal of Medicine, 31, 207.

Gunz, F. W. (1960). Blood, 15, 706.

Hardisty, R. M., and Wolff, H. H. (1955). British fournal of Haematology, 1, 390.

Lewis, S. M., Szur, L., and Hoffbrand, A. V. (1972). Clinics in Haematology, $1,339$.

Mills, D. C. B. (1972). Clinics in Haematology, 1, 295.

Ozer, F. L., et al. (1960). American fournal of Medicine, 28, 807.

Thomson, C., Forbes, C. D., and Prentice, C. R. M. (1973). Clinical Science and Molecular Medicine, 45, 485.

Vreeken, J., and Van Aken, W. G. (1971). Lancet, 2, 1394.

Youssef, A. H., and Barkhan, P. (1969). British Medical fournal, 3, 394.

\title{
Deaths from Occlusive Arterial Disease in Renal Allograft Recipients
}

\author{
L. S. IBELS, J. H. STEWART, J. F. MAHONY, A. G. R. SHEIL
}

British Medical fournal, 1974, 3, 552-554

\section{Summary}

In a series of 325 recipients of cadaveric renal transplants sudden occlusive arterial disease was found to be responsible for $12 \%$ of deaths. Acute myocardial infarction $(9 \%)$ occurred 25 times more than expected in the normal population and cerebral thrombosis $(3 \%) 300$ times more. The greatest loss was in the initial three-month period after transplantation. Patients with renal failure due to essential hypertension were especially at risk, accounting for six of the 12 deaths.

\section{Introduction}

The apparently high incidence of fatal arterial occlusive disease in renal allograft recipients (Australian National Renal Transplantation Survey, 1971; Advisory Committee to the Renal Transplant Registry, 1972; Brunner et al., 1972; Lowrie et al., 1973) suggests a higher mortality from these causes than in the normal population.

To determine the accuracy of this observation the mortality due to acute coronary and cerebral arterial thrombosis was determined in a consecutive series of 325 patients who received cadaveric renal transplants during a six-year period.

\section{Patients and Methods}

Between August 1967 and May 1973349 cadaveric renal transplant operations were carried out on 325 recipients at Sydney Hospital and the Royal Prince Alfred Hospital (Sheil et al., 1972, 1973). The total follow-up experience to May 1973 was 570 patient years, during which time there were 100 deaths. The causes of death were determined from necropsy and hospital clinical records.

\footnotetext{
Medical Research Department, Kanematsu Memorial Institute, Sydney Hospital, Sydney, Australia

L. S. IBELS, M.B., M.R.A.C.P., Senior Registrar, Immunology and Renal Unit J. H. STEWART, M.R.C.P., M.R.A.C.P., Associate Director

J. F. MAHONY, M.B., F.R.A.C.P., Physician, Immunology and Renal Unit

Department of Surgery, University of Sydney, Sydney, Australia A. G. R. SHEIL, F.R.C.S., F.R.A.C.S., Associate Professor
}

Age- and sex-specific death rates in Australia for acute myocardial infarction and cerebral thrombosis (respectively 410 and 433 in the international classification of causes of death) obtained from published data of the Commonwealth Bureau of Census and Statistics (O'Neill, 1971) were used to derive the expected mortality from these causes in the number of person years at risk in the transplant population. Since the probability of death from either of these causes is small statistical analysis was based on a Poisson approximation.

\section{Results}

Of the 100 deaths in this transplant population nine were certainly and two possibly due to acute coronary occlusion, and three resulted from cerebral thrombosis (table I). Necropsy confirmation was obtained in all three with cerebral thrombosis and in seven of the patients with coronary thrombosis. In the two other certain cases myocardial infarction was proven by serial electrocardiography and serum enzyme determinations after their admission to hospital with a clinical history suggestive of this diagnosis. Death was possibly due to coronary artery occlusion in two patients who died suddenly at home when in apparently good health (one had had severe atherosclerosis).

Seven deaths were due to cerebral haemorrhage. Three of these occurred in patients on anticoagulant therapy, and one was due to a ruptured cerebral aneurysm. In this study these seven deaths were excluded from further consideration.

Occlusive vascular mortality was greatest in the early posttransplantation period, and five deaths occurred in the first month and three others in the next two months after operation. Five of the nine patients dying from proven coronary artery occlusion had had ischaemic heart disease before transplantation. Graft function at the time of acute arterial occlusion was good in all but two patients (cases 9 and 14). In one further patient (case 4) poor graft function at the time of his death was due to prolonged hypotension resulting from his myocardial infarction.

The calculated expected mortality in this transplant population was 0.36 death from myocardial infarction and 0.01 from cerebral thrombosis. The observed mortalities-nine and three deaths-were respectively 25 times and 300 times greater, both highly significant increases.

When the renal allograft recipients were grouped according to their original renal disease those with essential hypertension had the highest overall death rate (table II). This was due to a mortality from occlusive arterial disease of $26 \%$, which was significantly higher than that of the patients in any of the other diagnostic categories except those with polycystic renal disease. 
TABLE I-Occlusive Arterial Deaths in Renal Allograft Recipients

\begin{tabular}{|c|c|c|c|c|c|c|c|c|}
\hline Case No. & Sex & Age at Death & $\begin{array}{c}\text { Primary } \\
\text { Renal } \\
\text { Disease }\end{array}$ & $\begin{array}{c}\text { Duration of } \\
\text { Dialysis } \\
\text { Therapy } \\
\text { (Months) }\end{array}$ & $\begin{array}{c}\text { Duration of } \\
\text { Graft } \\
\text { Function } \\
\text { (Months) }\end{array}$ & $\begin{array}{c}\text { Serum } \\
\text { Creatinine } \\
\text { at Death } \\
(\mathrm{mg} / 100 \mathrm{ml})\end{array}$ & $\begin{array}{l}\text { Documentation } \\
\text { of Cause } \\
\text { of Death }\end{array}$ & $\begin{array}{c}\text { Previous } \\
\text { Ischaemic } \\
\text { Heart } \\
\text { Disease }\end{array}$ \\
\hline \multicolumn{9}{|c|}{ Patients who died of Myocardial Infarction } \\
\hline $\begin{array}{l}1 \\
2\end{array}$ & $\begin{array}{l}\text { M. } \\
\text { M. }\end{array}$ & $\begin{array}{l}45 \\
48\end{array}$ & $\begin{array}{l}\text { G.N. } \\
\text { E.H. }\end{array}$ & $\begin{array}{l}5 \\
2.5\end{array}$ & $\begin{array}{r}1.9 \\
2 \cdot 0\end{array}$ & $\begin{array}{l}1 \cdot 2 \\
2 \cdot 2\end{array}$ & $\begin{array}{l}\text { Hospital records } \\
\text { Necropsy }\end{array}$ & $\begin{array}{l}\text { None } \\
\text { Acute coronary }\end{array}$ \\
\hline $\begin{array}{l}3 \\
4 \\
5\end{array}$ & $\begin{array}{l}\text { M. } \\
\text { M. } \\
\text { M. }\end{array}$ & $\begin{array}{l}43 \\
48 \\
45\end{array}$ & $\begin{array}{l}\text { G.N. } \\
\text { G.N. } \\
\text { E.H. }\end{array}$ & $\begin{array}{c}0 \cdot 5 \\
12 \\
1\end{array}$ & $\begin{array}{r}14 \cdot 6 \\
0.7 \\
0.6\end{array}$ & $\begin{array}{l}2 \cdot 1^{*} \\
7 \cdot 6 \dagger \\
2 \cdot 0\end{array}$ & $\begin{array}{l}\text { Necropsy } \\
\text { Necropsy } \\
\text { Hospital records }\end{array}$ & $\begin{array}{l}\text { insurticiency } \\
\text { None } \\
\text { None } \\
\text { Angina for }\end{array}$ \\
\hline $\begin{array}{l}6 \\
7\end{array}$ & $\begin{array}{l}\text { M. } \\
\text { F. }\end{array}$ & $\begin{array}{l}34 \\
40\end{array}$ & $\begin{array}{l}\text { E.H. } \\
\text { E.H. }\end{array}$ & $\begin{array}{l}4 \\
1\end{array}$ & $\begin{array}{r}16 \cdot 6 \\
0.5\end{array}$ & $\begin{array}{l}2 \cdot 1 \\
2 \cdot 3\end{array}$ & $\begin{array}{l}\text { Necropsy } \\
\text { Necropsy }\end{array}$ & $\begin{array}{l}\text { None } \\
2 \text { previous } \\
\text { myocardial }\end{array}$ \\
\hline 8 & M. & 46 & E.H. & 1.5 & $30 \cdot 6$ & $1 \cdot 8$ & Necropsy & Angina for \\
\hline 9 & M. & 57 & U.A.N. & 16 & $0 \cdot 2$ & $11 \cdot 0$ & Necropsy & $\begin{array}{l}5 \text { years } \\
\text { Angina for }\end{array}$ \\
\hline 10 & F. & 45 & A.N. & 3 & 0.7 & $1 \cdot 0$ & $\begin{array}{l}\text { Sudden death } \\
\text { at home }\end{array}$ & $\begin{array}{l}\text { None (severe } \\
\text { peripheral } \\
\text { vascular }\end{array}$ \\
\hline 11 & F. & 35 & G.N. & $5 \cdot 5$ & $14 \cdot 4$ & 1.6 & $\begin{array}{l}\text { Sudden death } \\
\text { at home }\end{array}$ & $\begin{array}{l}\text { disease) } \\
\text { None }\end{array}$ \\
\hline \multicolumn{9}{|c|}{ Patients who died from Cerebral Thrombosis } \\
\hline $\begin{array}{l}12 \\
13 \\
14\end{array}$ & $\begin{array}{l}\mathrm{F} \text {. } \\
\mathrm{F} .\end{array}$ & $\begin{array}{l}48 \\
40 \\
52\end{array}$ & $\begin{array}{l}\text { Calc. } \\
\text { E.H. } \\
\text { P.K. }\end{array}$ & $\begin{array}{l}11 \\
12 \\
21\end{array}$ & $\begin{array}{c}5.9 \\
8.8 \\
2.5 \text { weeks } \\
\text { after transplant } \\
\text { nephrectomy }\end{array}$ & $\begin{array}{l}1 \cdot 1 \\
1.5\end{array}$ & $\begin{array}{l}\text { Necropsy } \\
\text { Necropsy } \\
\text { Necropsy }\end{array}$ & $\begin{array}{l}\text { None } \\
\text { None } \\
\text { None }\end{array}$ \\
\hline
\end{tabular}

G.N. = Chronic glomerulonephritis. E.H. = Essential hypertension. U.A.N. = Uric acid nephropathy. A.N. = Analgesic nephropathy. Calc. = Calculous disease. P.K. = Polycystic renal disease.

TABLE II-Causes of Death in Renal Allograft Recipients Related to Underlying Renal Disease. Data expressed as Proportion of Patients

\begin{tabular}{|c|c|c|c|c|c|c|c|}
\hline \multirow[b]{2}{*}{ Causes of Death } & \multicolumn{7}{|c|}{ Primary Disease Causing Renal Failure } \\
\hline & $\begin{array}{c}\text { Glomerulo- } \\
\text { nephritis }\end{array}$ & $\begin{array}{c}\text { Analgesic } \\
\text { Nephropathy }\end{array}$ & $\begin{array}{c}\text { Essential } \\
\text { Hypertension }\end{array}$ & $\begin{array}{c}\text { Vesicoureteral } \\
\text { Reflux }\end{array}$ & $\begin{array}{l}\text { Polycystic } \\
\text { Kidneys }\end{array}$ & Other & Total \\
\hline No. of transplant recipients: & 145 & 78 & 23 & 23 & 13 & 43 & 325 \\
\hline $\begin{array}{l}\text { Infection } \\
\text { Complications of drug therapy } \\
\text { Vascular disease: } \\
\text { Myocardial infarction* }{ }^{*} \\
\text { Cerebral thrombosis } \\
\text { Cerebral haemorrhage } \\
\text { Ruptured aortic aneurysm } \\
\text { Technical causes } \\
\text { Other causes }\end{array}$ & $\begin{array}{r}19 \\
4 \\
4 \\
2 \\
1 \\
2 \\
9\end{array}$ & $\frac{\frac{14}{4}}{\frac{1}{1}}$ & $\begin{array}{l}2 \\
5 \\
1 \\
1 \\
1\end{array}$ & $\begin{array}{l}2 \\
= \\
\bar{E} \\
\frac{1}{2}\end{array}$ & $\begin{array}{l}1 \\
1 \\
1 \\
1 \\
=\end{array}$ & $\begin{array}{l}7 \\
2 \\
1 \\
1 \\
= \\
1\end{array}$ & $\begin{array}{r}45 \\
7 \\
11 \\
3 \\
7 \\
1 \\
5 \\
21\end{array}$ \\
\hline Total & $41\left(28^{\prime \prime}\right)$ & $28(36 \%)$ & $10(43 \%)$ & $5\left(22^{\circ}\right)$ & $4(31 \%)$ & $12\left(28^{\circ}\right)$ & $100\left(31_{0}^{\circ}\right)$ \\
\hline Percentage dead from occlusive vascular disease & $2 \cdot 8 \%+$ & $1 \cdot 3 \% \dagger$ & $26 \cdot 1 \%$ & $0^{\circ} \%$ & $7 \cdot 7 \%$ & $4 \cdot 7 \%$ & $4 \cdot 3 \%$ \\
\hline
\end{tabular}

*Includes two patients in whom the diagnosis was not proven (see text).

Significance of difference between mortality from occlusive vascular disease in essential hypertension and that in other diagnostic categories by $\%^{2}$ analysis: $\underset{+P}{+P}<0.001$.

\section{Discussion}

Sudden cardiac or cerebrovascular death, which is a major cause of death in the haemodialysis population, has become recognized as an important factor in the success of renal replacement programmes (Cohen et al., 1970; Burton et al., 1971; Brunner et al., 1972; Lowrie et al., 1973).

The present series confirms that in cadaveric allograft recipients fatal occlusive arterial disease is much more common than in the population at large. That these deaths occurred more often in the early post-transplantation period implies that the stress of operation and heavy immunosuppressive therapy, including high-dose corticosteroids, were important precipitating factors in patients with pre-existing arterial disease. Chronic renal failure is accompanied by several factors implicated in the pathogenesis of atherosclerosis, in particular hypertension, hypertriglyceridaemia (Bagdade et al., 1968; Dombeck et al., 1973), hyperparathyroidism and phosphate retention resulting in vascular calcification (Parfitt, 1969; Rosen et al., 1972) and hyperuricaemia. Such factors may have been present for many years before transplantation. In addition after transplantation persistent hypertension, hyperlipidaemia (Ibels et al., 1973;
Casaretto et al., 1973; Ghosh et al., 1973), and the necessity for permanent therapy with relatively large doses of corticosteroids may cause further arterial disease (Kannell et al., 1971; Carlson and Böttiger, 1972; Kalbak, 1972).

The somewhat higher mortality from myocardial infarction in this series than in other reports (Reeve et al., 1969; Pletka et al., 1969; Starlz et al., 1970; Advisory Committee to the Renal Transplant Registry, 1972; Brunner et al., 1972) may be due to the acceptance into our renal replacement programme of patients with known ischaemic heart disease.

A reduced survival after transplantation has been reported for patients with renal failure due to malignant hypertension (Advisory Committee to the Renal Transplant Registry, 1972), a finding in accord with the observation that six of the 12 fatal vascular occlusions in this series were in patients with this diagnosis. The high incidence of vascular complications in essential hypertension is not surprising in view of the arterial damage that must accompany hypertension severe enough to have caused renal failure. It has been suggested that earlier bilateral nephrectomy in patients with renal failure due to malignant hypertension might reduce the incidence of subsequent fatal arterial disease (Lazarus and Hampers, 1972). 


\section{References}

Advisory Committee to the Renal Transplant Registry (1972). Fournal of the American Medical Association, 220, 253.

Australian National Renal Transplantation Survey (1971). Medical fournal of Australia, 2, 605.

Bagdade, J. D., Porte, D., and Bierman, E. L. (1968). New England Fournal of Medicine, 279, 181 .

Brunner, F. P., et al. (1972). Proceedings of the European Dialysis and Transplant Association, 9, 3.

Burton, B. T., Krueger, K. K., and Bryan, F. A. (1971). Fournal of the American Medical Association, 218, 718.

Carlson, L. A., and Böttiger, L. E. (1972). Lancet, 1, 865.

Casaretto, A. A., Marchioro, T. L., and Bagdade, J. D. (1973). Transactions of the American Society for Artificial Internal Organs, 19, 154

Cohen, S. L., Comty, C. M., and Shapiro, F. L. (1970). Proceedings of the European Dialysis and Transplant Association, 7, 254.

Dombeck, D. H., Lindholm, D. D., and Vieira, J. A. (1973). Transactions of the American Society for Artificial Internal Organs, 19, 150.
Ghosh, P., et al. (1973). Transplantation, 15, 521.

Ibels, L. S., et al. (1973). Australian and New Zealand fournal of Medicine,

Kalbak, J. (1972). Annals of the Rheumatic Diseases, 31, 196.

Kalbak, J. (1972). Annals of the Rheumatic Diseases, 31, 196.
Kannell, W. B., et al. (1971). Annals of Internal Medicine, 74, 1.

Lazarus, J. M., and Hampers, C. L. (1972). Annals of Internal Medicine, 76, 504.

Lowrie, E. G., et al. (1973). New England fournal of Medicine, 288, 863.

O'Neill, J. P., Causes of Death, Bulletin No. 8. (1971 p. 70. Canberra, Commonwealth Bureau of Census and Statistics.

Parfitt, A. M. (1969). Archives of Internal Medicine, 124, 544.

Pletka, P., et al. (1969). Lancet, $1,1$.

Reeve, C. E., et al. (1969). American fournal of Medicine, 47, 410.

Rosen, H., et al. (1972). American Heart fournal, 84, 250.

Sheil, A. G. R., et al. (1972). Medical fournal of Australia, 1, 205.

Sheil, A. G. R., et al. (1973). Lancet, 2, 227.

Starzl, T. E., et al. (1970). Annals of Surgery, 172, 437.

\section{Effect of Histamine $\mathrm{H}_{2}$-Receptor Blockade on Vagally Induced Gastric Secretion in Man}

\author{
D. C. CARTER, J. A. H. FORREST, M. WERNER, \\ D. J. C. SHEARMAN
}

British Medical fournal, 1974, 3, 554-556

\section{Summary}

Metiamide, an antagonist of histamine $\mathbf{H}_{2}$ receptors, was administered intravenously to normal subjects and to patients with a peptic ulcer during vagal stimulation with a constant infusion of insulin. In normal and peptic-ulcer subjects there were reductions of $70 \%$ and $71 \%$ respectively in gastricacid output compared with control tests on the same subjects. The decreased acid output resulted from a reduction in both volume of secretion and acid concentration. Metiamide is therefore a potent inhibitor of vagally-induced gastric acid secretion.

\section{Introduction}

Certain actions of histamine in the body, such as the stimulation of smooth muscle in the gut and bronchi, are antagonized by mepyramine. Ash and Schild (1966) termed such mepyramine-sensitive receptors $\mathrm{H}_{1}$ receptors and suggested that those actions of histamine which were unaffected by mepyramine, including the stimulation of gastric secretion, were mediated by a second type of receptor. This second group, now known as $\mathrm{H}_{2}$ receptors, was defined by Black et al. (1972) when they described the properties of burimamide, the first selective $\mathrm{H}_{2}$ receptor antagonist.

The $\mathrm{H}_{2}$ receptor antagonists, burimamide and its more potent analogue metiamide (fig. 1), antagonize the stimulation of gastric secretion in man both by histamine and pentagastrin (Wyllie and Hesselbo, 1973). These findings have rekindled controversy as to the physiological role of hista-

Departments of Clinical Surgery and the Gastrointestinal Section, University Department of Therapeutics, Royal Infirmary, Edinburgh EH3 9YW

D. C. CARTER, M.B., F.R.C.s., Lecturer

J. A. H. FORREST, M.B., M.R.C.P., Medical Registrar

M. WERNER, M.D., Research Assistant

R. C. HEADING, M.B., M.R.C.P., Lecturer
J. PARK, M.B., M.R.C.P., Medical Registrar

J. PARK, M.B., M.R.C.P., Medical Registrar
D. J. C. SHEARMAN, PH.D., F.R.C.P., Consultant Physician
R. C. HEADING, J. PARK, (2)

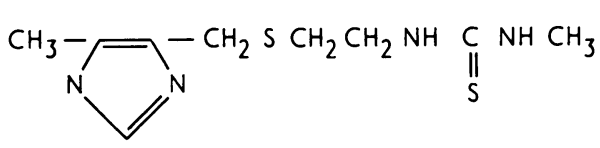

FIG. 1-Chemical structure of metiamide.

mine in gastric secretion and have suggested that $\mathrm{H}_{2}$ receptor antagonists might have therapeutic value in the treatment of peptic ulcer.

The present experiments were undertaken to assess the effect of metiamide on vagally-induced gastric secretion in man using the insulin infusion test as a constant vagal stimulus (Carter et al., 1972).

\section{Patients and Methods}

\section{HEALTHY VOLUNTEERS}

Paired insulin infusion tests were carried out in six healthy male volunteers with no previous dyspeptic history and ranging in age from 27 to 34 years.

After a 12-hour overnight fast the subject was intubated as described by Hassan and Hobsley (1970). The tests began with collection of two 15-minute samples of basal gastric secretion after which insulin $(0.03 \mathrm{U} / \mathrm{kg} / \mathrm{hr})$ were infused intravenously for 150 minutes while gastric juice was collected every 15 minutes. All samples were assessed in terms of volume $(\mathrm{ml}), \mathrm{pH}$, acid concentration $(\mathrm{mmol} / \mathrm{l}$.), and acid output (mmol). All titrations were carried out to end-point $\mathrm{pH} 7$ using $0.1 \mathrm{~N} \mathrm{NaOH}$ solution, a glass $\mathrm{pH}$ electrode, and an automatic titrator (Radiometer, Copenhagen).

After 60 minutes of insulin infusion a second intravenous infusion was begun in the opposite arm. In tests using metiamide $250 \mathrm{mg}$ of the drug diluted to $13.2 \mathrm{ml}$ with normal saline was delivered at a constant rate of $200 \mathrm{mg} / \mathrm{hr}$ for 75 minutes. In the control tests the technique was identical but for the omission of metiamide from the saline vehicle. The order of the paired tests was randomized and unknown to the subject. The interval between the two tests was less than two weeks in all but one of the subjects in whom the tests were six weeks apart. 